Hyrdrogen Energy

https://doi.org/10.52825/thwildauensp.v1i.9

(C) Authors. This work is licensed under a Creative Commons Attribution 4.0 International License

Published:15 June 2021

\title{
Sustainably Produced Hydrogen
}

\section{Possible Variants and its Main Supply Paths}

\author{
Maria Gribova ${ }^{1}$, Lutz B. Giese ${ }^{2}$ \\ ${ }^{1}$ Technische Hochschule Wildau (Graduate), Germany \\ ${ }^{2}$ Technische Hochschule Wildau, Germany
}

Abstract: The fossil fuels used to provide energy, such as coal, crude oil and natural gas, are largely responsible for carbon dioxide emissions and other so-called greenhouse gases. Hydrogen gas $\left(\mathrm{H}_{2}\right)$ can make a key contribution to decarbonization. It can be produced using various processes. Several processes are available to produce hydrogen, such as (i) steam reforming, (ii) cracking process or (iii) electrolysis. Depending on the source of origin, there is a distinction made between different "colours". Gray, blue, turquoise, yellow and green hydrogen is available, the latter made using Renewable Energies. However, items such as (i) possible variants of hydrogen, (ii) leading export countries or (iii) provision paths to be preferred in the future will be discussed in this paper.

Keywords: Hydrogen, Green Gas Supply, Renewable Energy Sources

\section{Introduction}

According to the "Energy Data, Complete Edition" of the German Federal Ministry for Economic Affairs and Energy (BMWi), worldwide carbon dioxide emissions in 2018 were 34.0 billion tons per year [1]. With around 731 million tons, Germany had a share of around $2 \%$ with a world population share of around $1 \%$. The total emissions of the European Union amounted to 3.47 billion t per year in 2018 (in comparison: Africa as a whole, on the other hand, had only 1.28 billion t per year with 1.3 billion inhabitants [2]). In spite of relevant agreements in 2015 via the Paris Agreement, these emissions are still on the rise. The fossil fuels used to provide energy, such as coal, crude oil and natural gas, are largely responsible for these carbon dioxide emissions and for a certain part of the so-called greenhouse gases, which, in addition to $\mathrm{CO}_{2}$, combine methane $\left(\mathrm{CH}_{4}\right)$ and nitrous oxide $\left(\mathrm{N}_{2} \mathrm{O}\right)$ to form relevant part of the $\mathrm{CO}_{2}$-equivalents and thus contribute significantly to climate change. A German citizen still emits approximately $10 \mathrm{t} \mathrm{CO}_{2}$ yearly, an average Europe has a per capita emission of approximately $8 \mathrm{t} \mathrm{CO}_{2}$ yearly. Renewable energies and hydrogen as a gaseous energy carrier obtained from them are seen as essential means to change this situation in the near future and to avert harmful climate change as far as possible.

Thus, hydrogen gas $\left(\mathrm{H}_{2}\right)$ can make a key contribution to decarbonization. Its versatile use as (i) raw material and fuel in industry, as (ii) fuel in mobility, as (iii) energy storage and as (iv) energy source in the provision of heat enables sector coupling, which can take place on the basis of an energy source, whose combustion product is only water. In 1874, the French science-fiction author Jules Verne wrote, that "Water Will Be the Coal of the Future" [3]. But hydrogen can only make a contribution to decarbonization if it is produced with low emissions. 


\section{Hydrogen}

\section{Characteristics and Physicochemical Properties of Hydrogen}

Hydrogen is the lightest element and is composed of a mixture of three isotopes, the main part is (i) ${ }^{1} \mathrm{H}$, in addition there are traces of (ii) $\mathrm{D}\left({ }^{2} \mathrm{H}\right.$, deuterium) and the radioactive $\mathrm{T}\left({ }^{3} \mathrm{H}\right.$, tritium). Hydrogen is significantly lighter than air, the standard cubic meter $\left(\mathrm{Nm}^{3}\right.$, at $1.013 \mathrm{bar}$ and $273.15 \mathrm{~K}$ ) weighs only around $89.9 \mathrm{~g}$. Hydrogen is flammable, can form explosive mixtures, is highly diffusive and has an embrittling effect on materials such as steal e.g. of system components or pipelines. Thus, dealing with hydrogen requires certain technical precautions.

For compression and storage, the high volatility, the very low boiling point and the low critical point must also be taken into account (Table 1).Please notice that there is no indent in the first paragraph of a section or subsection. There also no indent in the first paragraphs which follow a table, figure, equation, etc.

Table 1. Properties of hydrogen [4].

\begin{tabular}{|l|l|l|}
\hline Property & Value & Unit \\
\hline Density (as gas) & 0.0899 & $\mathrm{~kg} / \mathrm{Nm}^{3}$ (per standard cubic meter) \\
\hline Density (as liquid) & 70.79 & $\mathrm{~kg} / \mathrm{m}^{3}$ (per cubic meter of liquid) \\
\hline Melting temperature & 14.01 & $\mathrm{~K}$ \\
\hline Boiling temperature & 21.15 & $\mathrm{~K}$ \\
\hline Critical point & 33.18 & $\mathrm{~K}(13.0 \mathrm{bar}$ ) \\
\hline Lower calorific value & 3.0 & $\mathrm{kWh} / \mathrm{Nm}^{3}$ (per standard cubic meter) \\
\hline & 33.33 & $\mathrm{kWh} / \mathrm{kg}^{\text {(by weight) }}$ \\
\hline & 2.79 & $\mathrm{kWh} / \mathrm{l}$ (per cubic meter of liquid) \\
\hline Upper calorific value & 3.5 & $\mathrm{kWh} / \mathrm{Nm}^{3}$ (per standard cubic meter) \\
\hline & 39.41 & $\mathrm{kWh} / \mathrm{kg}_{\text {(by weight) }}$ \\
\hline
\end{tabular}

\section{Provision of Hydrogen}

Elemental hydrogen does not exist naturally on earth, but in chemically bound form in water, organic compounds and rocks. However, it can be produced using various processes, e.g. by splitting water or hydrocarbons. Several processes are available, essentially (i) steam reforming, (ii) the cracking process and (iii) electrolysis. Depending on the source of origin, a distinction is made between different "colours" [5] [6]:

- Gray hydrogen

- Manufactured from natural gas via steam reforming (SMR or ATR process) with full greenhouse gas emissions

- Blue hydrogen

- Manufactured from natural gas via steam reforming with partial greenhouse gas reduction via CCS (carbon capture and storage; SMR: -60\%; ATR: $-90 \%$ )

- Turquoise hydrogen

- Manufactured from natural gas via methane pyrolysis (cracking process) with low greenhouse gas emissions

- Yellow hydrogen

- Manufactured using nuclear energy with lower greenhouse gas emissions, e.g. using electrolysis with nuclear power

- Green hydrogen

- Manufactured using renewable energies with little to no greenhouse gas emissions, e.g. via electrolysis with solar or wind power 
Nowadays, hydrogen is used in a variety of material and energetic ways, e.g. in the manufacture of fertilizers or to drive spacecraft (Figure 1). More than $90 \%$ of hydrogen is currently generated from fossil fuels, often from natural gas (methane) by the catalytic steam reforming $\left(\Delta \mathrm{H}_{\mathrm{R}(\mathrm{I})}=+206.2 \mathrm{~kJ} / \mathrm{mole} \mathrm{CH}_{4} ; \Delta \mathrm{H}_{\mathrm{R}(\mathrm{II})}=-41.2 \mathrm{~kJ} / \mathrm{mole} \mathrm{CO}\right.$ [7]; compare grey/ blue hydrogen):

$$
\begin{aligned}
& \text { (I) } \mathrm{CH}_{4}(\mathrm{~g})+\mathrm{H}_{2} \mathrm{O}(\mathrm{g}) \rightarrow 3 \mathrm{H}_{2}(\mathrm{~g})+\mathrm{CO}(\mathrm{g}) \\
& \text { (II) } \mathrm{CO}+\mathrm{H}_{2} \mathrm{O}(\mathrm{g}) \rightarrow \mathrm{H}_{2}(g)+\mathrm{CO}_{2}(g)
\end{aligned}
$$

Available process variations are

- $\quad$ steam reforming (SMR = Steam Methane Reforming),

- partial oxidation (POX), and

- dry reforming or autothermal reforming (ATR).

Hereby, the SMR and ATR process allow parts of the carbon dioxide formed during steam reforming to be separated from the synthesis gas mixtures, e.g. to render it inert by underground storage. This sequestration of carbon dioxide is also known as carbon capture and storage (CCS). The CCS process is only popular to a limited extent among climate protectionists.

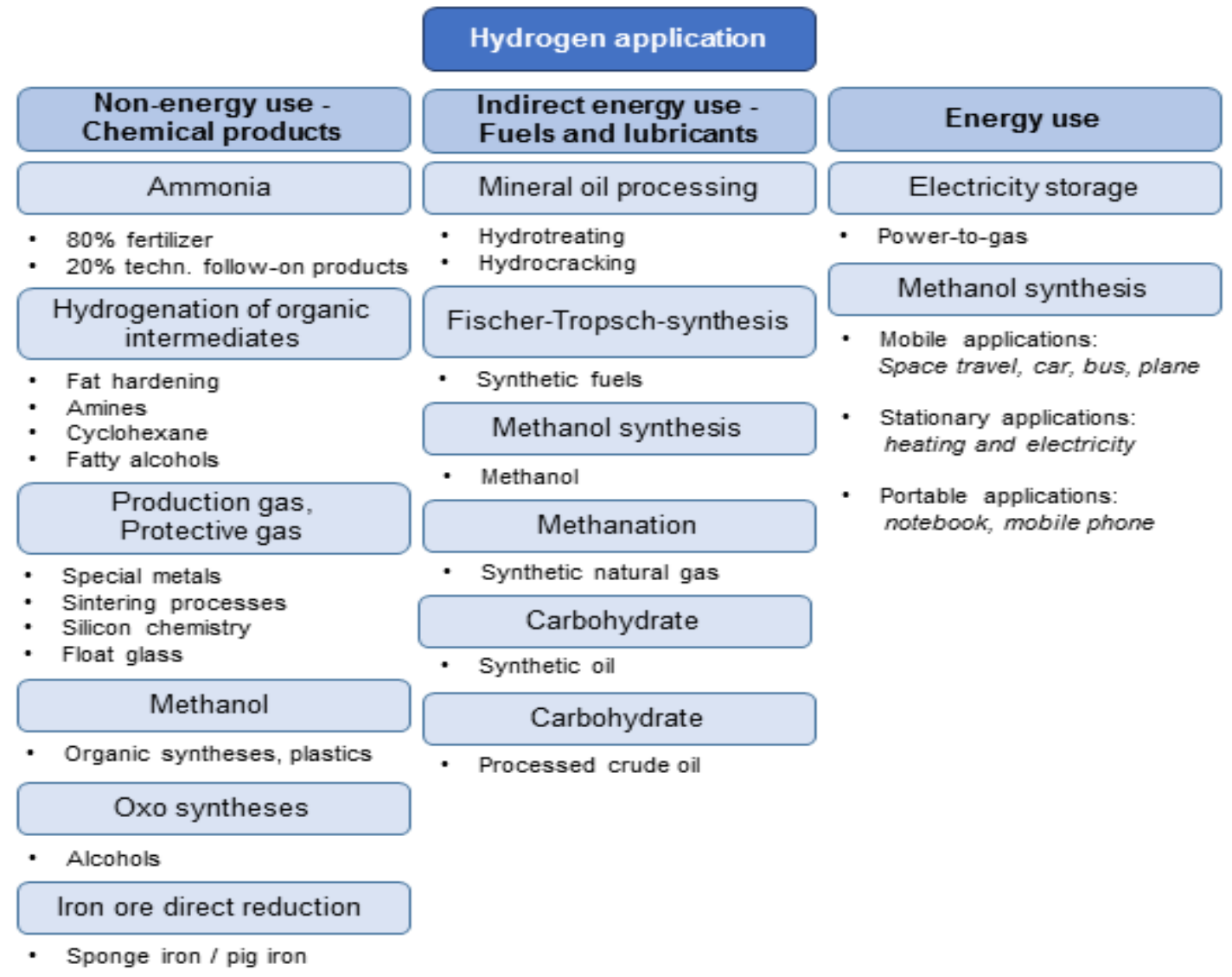

Figure 1. Today's material and energetic use of hydrogen [8] [9].

An alternative process is the methane cracking (methane pyrolysis), revised by the IASS Potsdam and KIT Karlsruhe for the environmentally friendly and efficient production of hydrogen from natural gas (methane) in addition to graphite powder (compare turquoise hydrogen; $\Delta \mathrm{H}_{\mathrm{R}}=+74.9 \mathrm{~kJ} / \mathrm{mole} \mathrm{CH}_{4}$ ) [7]:

$$
\mathrm{CH}_{4}(\mathrm{~g}) \rightarrow 2 \mathrm{H}_{2}(\mathrm{~g})+\mathrm{C}(\mathrm{s}) \downarrow
$$

In this case, small methane bubbles are placed from below into a column filled with molten tin. The cracking reaction takes place while they are rising in the liquid metal. The carbon is 
deposited on the surface of the bubbles and, when the bubbles disintegrate, deposited as a powder at the top of the reactor. More than $75 \%$ of the methane can be converted into hydrogen at $1200^{\circ} \mathrm{C}$. The process could take on the role of a bridging technology. With it, the energy potential of natural gas could be used in a more climate-friendly way. Thus, the integration of the clean energy carrier hydrogen into the energy system could be made easier [10].

Renewable energies are of course the most environmentally friendly source of producing hydrogen (compare green hydrogen; see Figure 2). In addition to biogas fermentation, biomass gasification or its pyrolysis (partly with reforming), the use of renewable electricity for water electrolysis is certainly the best alternative. Electrolysis processes are therefore particularly suitable for the climate-friendly production of hydrogen. The ecological rucksack of the individual conversion methods is decisive for the greenhouse gas reduction, but this also means that the amount of green hydrogen available via electrolysis is directly dependent on the amount of renewable electricity provided or its primary energy resources. Today these are essentially wind power, biomass and photovoltaics, or possibly also hydropower, solar thermal power plants and geothermal energy. In general, however, the demand for renewable electricity will increase significantly by 2100 , presumably for reasons of growth of population and standards, the introduction of e-mobility, but also the needs of ecological transformation of technologies.

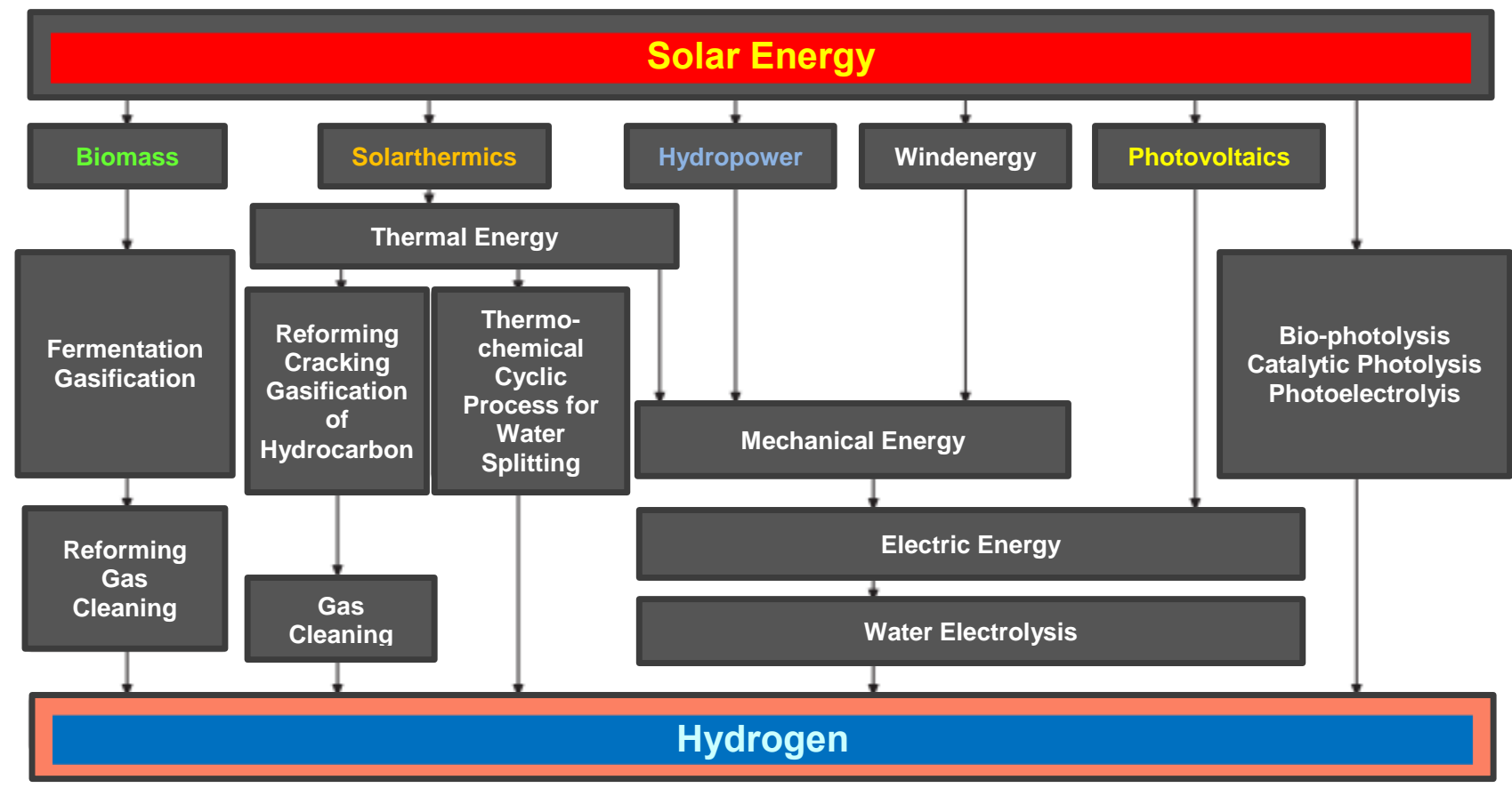

Figure 2. Energy conversion steps of non-fossil, renewable hydrogen production [11].

However, electrolysis processes achieve efficiencies in excess of $70 \%$. Here, water is split into its components hydrogen and oxygen $\left(\Delta \mathrm{H}_{\mathrm{R}}=+285.8 \mathrm{~kJ} / \mathrm{mole}_{2} \mathrm{O}\right)[7]$ :

$$
\mathrm{H}_{2} \mathrm{O}(\mathrm{I}) \rightarrow 2 \mathrm{H}_{2}(\mathrm{~g}) \uparrow+\mathrm{O}_{2}(\mathrm{~g}) \uparrow
$$

The process of producing hydrogen by electrolysis of water has been state of the art for over 100 years (chlorine-alkali electrolysis). Basically, three different types of electrolysis processes can be distinguished from one another according to the type of ion-conducting electrolyte, the operating temperature and the level of development:

- Alkaline electrolysis (AEL)

- Polymer electrolyte membrane electrolysis (PEMEL)

- High temperature electrolysis (SOEC) 

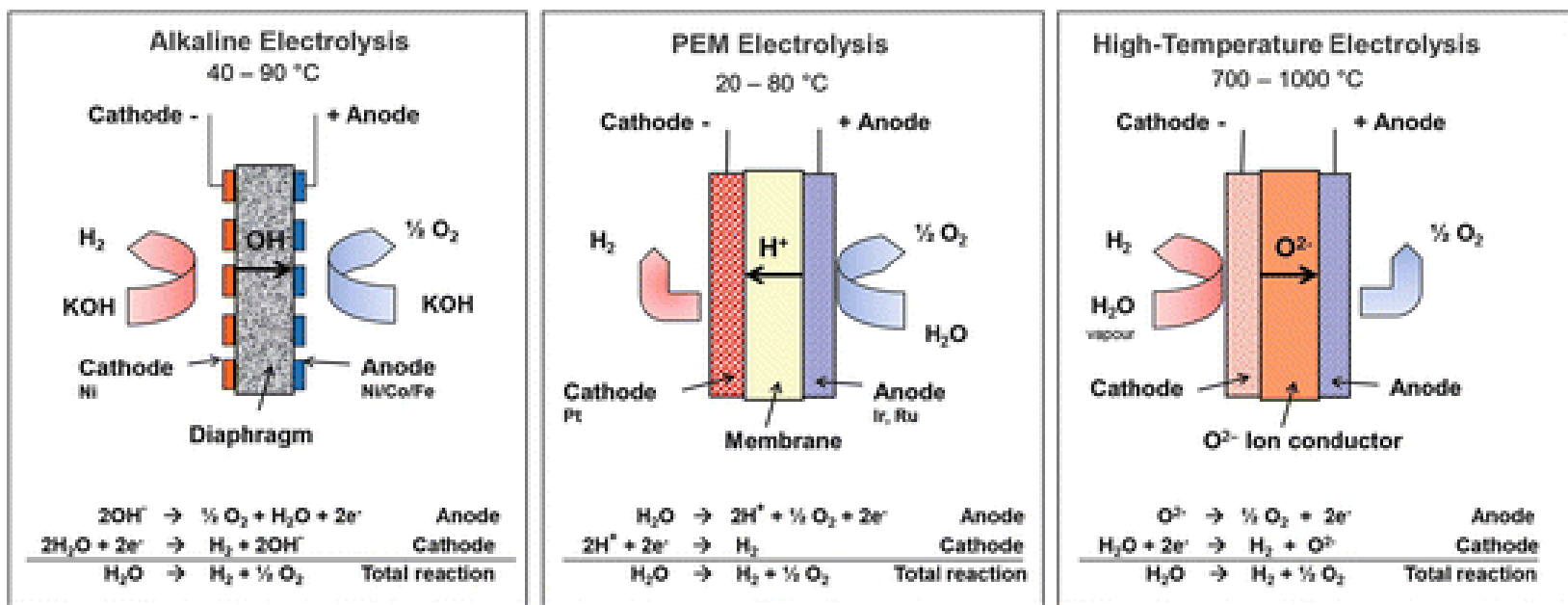

Figure 3. Functional principles of electrolysis cells and various electrolysis processes [4].

The functional principle of each individual electrolysis cell and the reaction equations are shown in Figure 3. A comprehensive technology comparison between alkaline and PEM electrolysis is shown in Table 2.

Table 2. Technology comparison between AEL and PEMEL electrolysis [12].

\begin{tabular}{|l|l|l|}
\hline & AEL & PEMEL \\
\hline Operating temperature & $60^{\circ}-80^{\circ} \mathrm{C}$ & $50^{\circ}-80^{\circ} \mathrm{C}$ \\
\hline System pressure & $<30 \mathrm{bar}$ & $<40 \mathrm{bar}$ \\
\hline Current density & $0.2-0.4 \mathrm{~A} / \mathrm{cm}^{2}$ & $0.6-2.0 \mathrm{~A} / \mathrm{cm}^{2}$ \\
\hline Cell voltage & $1.8-2.4 \mathrm{~V}$ & $1.8-2.2 \mathrm{~V}$ \\
\hline Specific energy consumption & $\begin{array}{l}\text { press.less: } 4,3-4,6 \mathrm{kWh} / \mathrm{Nm}^{3} \mathrm{H}_{2} \\
\text { pressure: } 4.5-5.0 \mathrm{kWh} / \mathrm{Nm}^{3} \mathrm{H}_{2}\end{array}$ & $4.9-6.7 \mathrm{kWh} / \mathrm{Nm}^{3} \mathrm{H}_{2}$ \\
\hline Lower partial load range & $20-40 \%$ & $0-10 \%$ \\
\hline Efficiency & $62-82 \%$ & $67-82 \%$ \\
\hline $\mathrm{H}_{2}$ production rate per stack/ & $<760 \mathrm{Nm}^{3} / \mathrm{h}$ & per Stack $<10 \mathrm{Nm}^{3} / \mathrm{h}$ \\
\hline Useful life & $<90,000 \mathrm{~h}$ & $<20,000 \mathrm{~h}$ \\
\hline
\end{tabular}

Every type of hydrogen has its potential leading export countries. Which provision path is preferred in the future from an ecological and economic point of view and which opportunities open up for Africa will be discussed in this publication.

\section{Storage, Transport and Distribution of Hydrogen}

Important further points in the logistics of the use of hydrogen should only be briefly addressed here. The storage of hydrogen, the transport and the distribution are often difficult due to the specific physical properties, e.g. with regard to compression, shelf life, corrosiveness, etc..

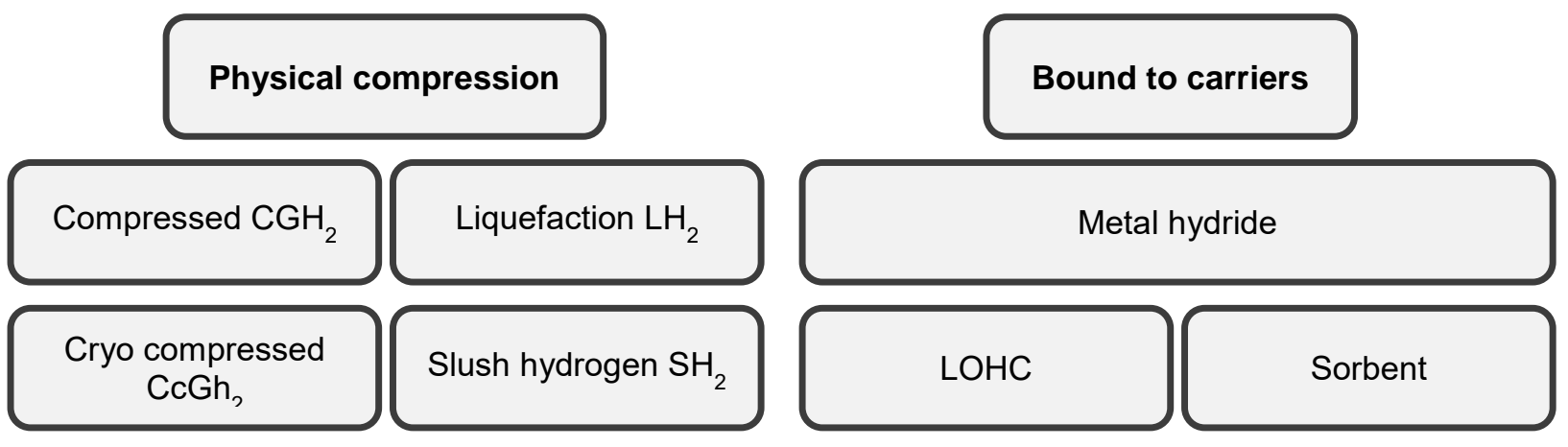

Figure 4. Types of hydrogen storage [13]. 
The storage concepts include the options to be seen in Figure 4. Some of those storage technologies are useful for transport of hydrogen, as well. So-called LOHC such as dibenzyltoluene are of special interest as pressure-less hydrogen carrier materials with high energy density. This technology can be applied as static storage or for transporting of hydrogen as well as after distribution as a mobile fuel.

Preliminary studies and initial field tests are being carried out currently in order to test the admixture of hydrogen in natural gas pipelines with the aim of long-distance transport.

\section{Application Goals and Possible Supplier Countries}

Power-to-Gas (PtG or P2G) is often referred to as the key technology of the energy transition, as it is the central coupling element between electricity and gas infrastructure, which enables the production of renewable gases and the storage of energy from RES resources on a large-scale volume realized over longer periods of time (Figure 5).

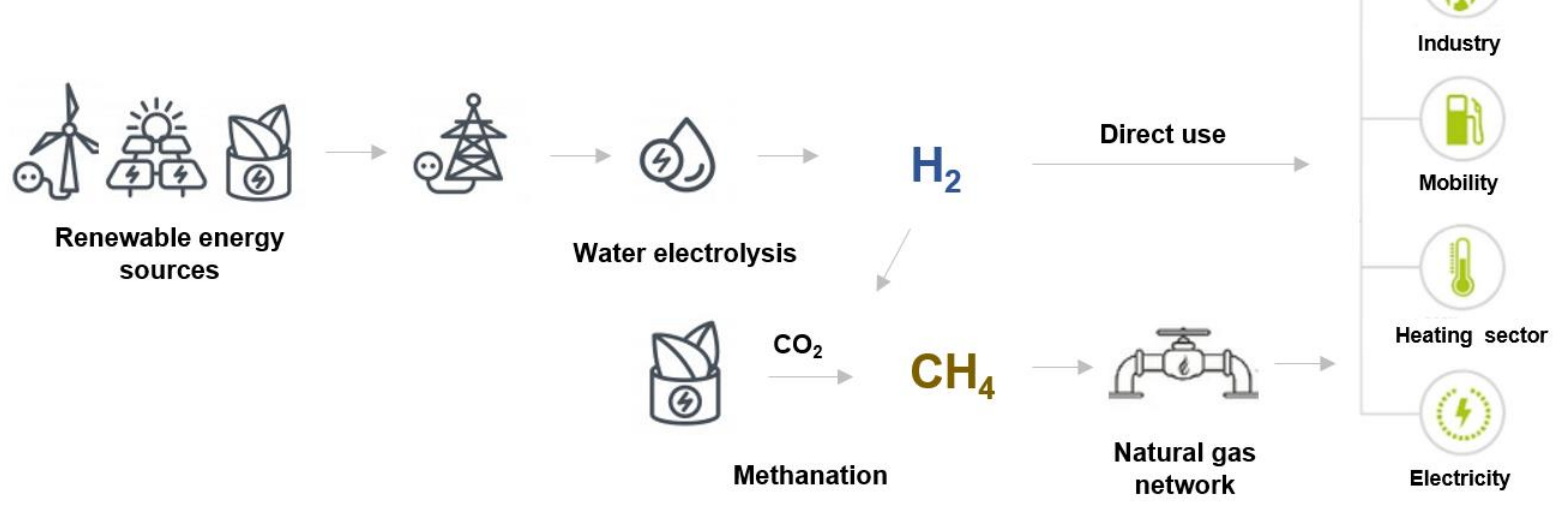

Figure 5. The Power-to-Gas concept [9] (adapted from [14]).

The hydrogen produced offers the possibility of storage in large quantities over longer periods of time (e.g. underground) and can later be converted back into electricity without $\mathrm{CO}_{2}$ through cold (electrochemical) combustion using fuel cell technology. On the other hand, hydrogen can also be transported directly to the place of consumption or converted into methane beforehand by adding carbon monoxide or carbon dioxide. The process is known as methanation and is used, among other things, to store green methane in existing natural gas networks (compare Equation 1 and 2). In addition, the required $\mathrm{CO}_{2}$ from biogas plants can be bound in the methanation process and thus does not get into the atmosphere.

\section{Potential Hydrogen Suppliers}

Each type of hydrogen has its potential supplier countries. Potential hydrogen suppliers differ according to the type of original energy source for hydrogen production. The transition from conventional energy sources to the hydrogen economy only makes sense if there are ecological relief effects. For this reason, the production of gray or yellow hydrogen on an industrial scale is not planned in the future. Table 3 shows the $\mathrm{CO}_{2}$ emissions for each type of hydrogen production.

Table 3. Carbon dioxide emissions depending on the type of hydrogen production [15].

\begin{tabular}{|c|c|c|c|c|}
\hline & \multicolumn{2}{|l|}{ GHG average } & \multicolumn{2}{|c|}{ Thereof upstream emissions } \\
\hline $\mathrm{H}_{2}$-origin & $\mathrm{kg} \mathrm{CO}_{2} / \mathrm{kg} \mathrm{H}_{2}$ & $\mathrm{~g} \mathrm{CO}_{2} / \mathrm{kWh}$ & $\mathrm{kg} \mathrm{CO} / \mathrm{kg} \mathrm{H}$ & $\mathrm{g} \mathrm{CO}_{2} / \mathrm{kWh}$ \\
\hline Gray & 13.24 & 398 & 3.24 & 98 \\
\hline Blue & 5.61 & 168 & 3.24 & 98 \\
\hline Green & 0.88 & 26 & - & - \\
\hline Turquoise & 6.1 & 183 & 3.24 & 98 \\
\hline
\end{tabular}


The production of gray, blue and turquoise hydrogen is based on natural gas and is therefore not emission-free. This is due to the upstream emissions. Greenhouse gases are released into the atmosphere during the extraction, processing and transport of natural gas. Greenpeace Energy attributes $25 \%$ of the total emissions (upstream chain and combustion/ use) of natural gas to the upstream chain emissions [15].

The production of green hydrogen is also not completely without a negative effect on the $\mathrm{CO}_{2}$ footprint. This is due to the upstream chain emissions in the manufacture of wind or solar systems as well as electrolyzers. The electrolysis with wind power produces $26 \mathrm{~g} \mathrm{CO}_{2} / \mathrm{kWh} \mathrm{H}_{2}[15]$.

\section{Blue and Turquoise Hydrogen from Russia}

The import of natural gas from Russia offers a possible supply path for blue hydrogen. The natural gas is converted into gray - and then blue - hydrogen using SMR or ATR processes, in that the carbon dioxide produced is "captured" and stored underground. The process is known as carbon capture and storage (CCS). Similar to this underground storage of carbon dioxide the sub-surface storage of hydrogen in exhausted natural gas and oil deposits or natural structures is planned. However, Figure 6 shows one of the possible deployment paths.

The use of blue hydrogen represents the bridge into the hydrogen age. Due to the limited storage capacity underground, a comprehensive CCS application can lead to storage problems.

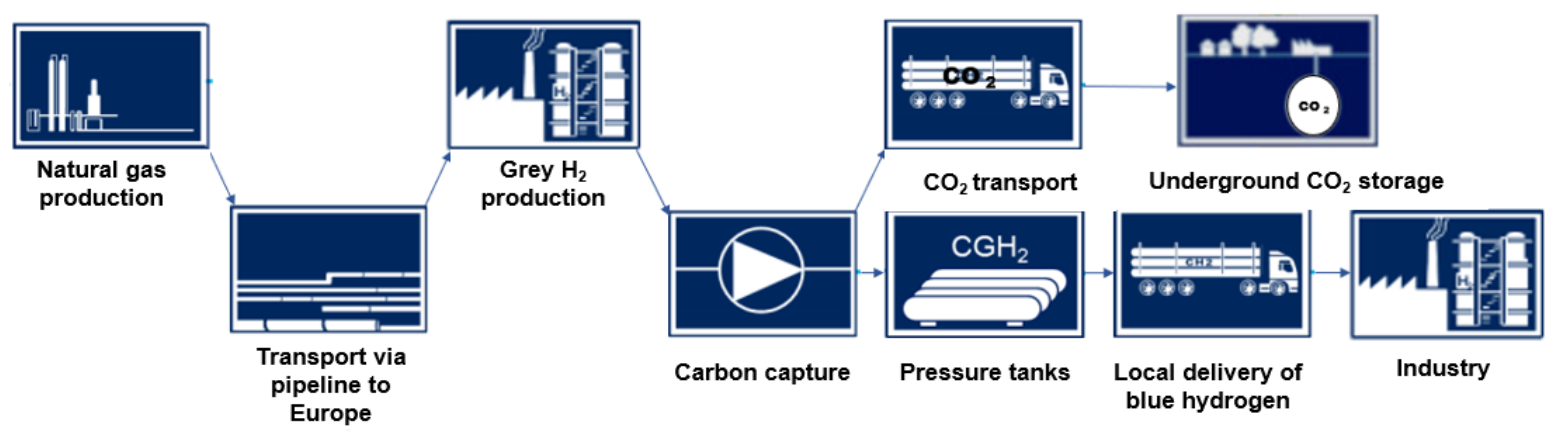

Figure 6. Delivery path - blue hydrogen from Eastern Europe (Russia) [9].

Another option for importing hydrogen is delivery by pipeline from Russia. This is $\mathrm{CO}_{2}$-neutral turquoise hydrogen, which is created through the thermal splitting of methane (methane pyrolysis). Since no oxygen is involved in the fission process, only solid carbon is created as a by-product instead of the greenhouse gas $\mathrm{CO}_{2}$. The largest natural gas supplier from Russia, Gazprom, is currently developing processes on an industrial scale. This means that the natural gas can be decarbonized in the immediate vicinity of the production source. The deployment path is shown schematically in Figure 7.

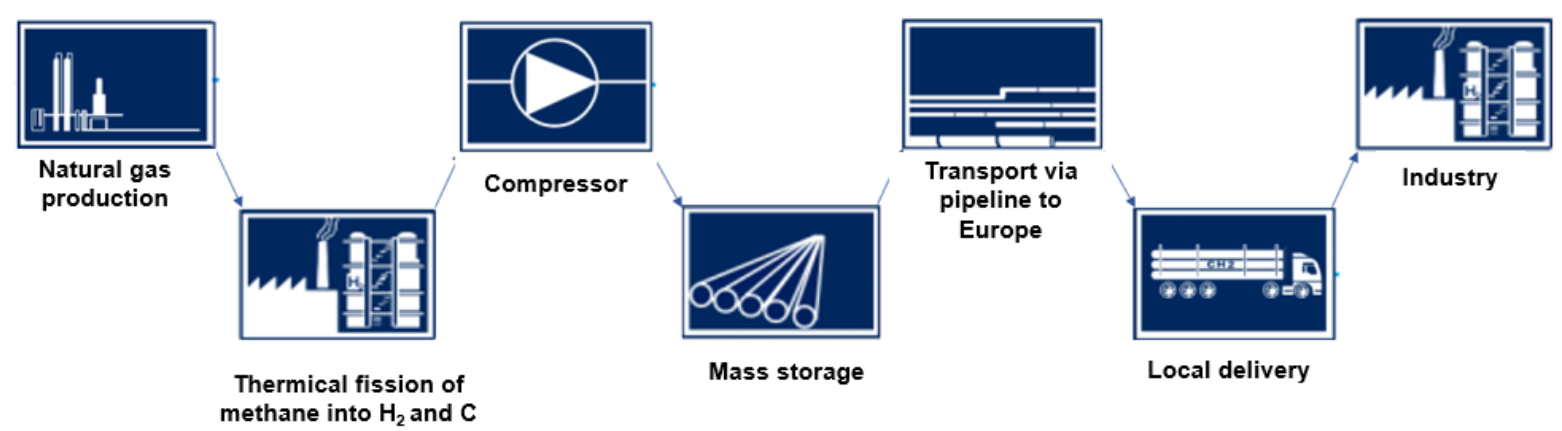

Figure 7. Delivery path - turquoise hydrogen from Russia [9]. 


\section{Green Hydrogen from Africa}

Due to the great potential for solar and wind energy as well as sufficient space for the development of RES, the German Federal Ministry of Education and Research BMBF relies primarily on cooperation with West and South Africa [16]. The Federal Ministry of Research has requested the "Hydrogen Potential Atlas", which is to examine the areas of the African continent for the potential of production and export. Firstly, an interactive map is to be developed within the scope of this project, which has to show the most compatible locations for the construction of an infrastructure for the production of green hydrogen. Second, the project should then show through pilot projects how the export and sale of green-generated hydrogen can be organized most efficiently.

One of the possible hydrogen supply paths from Africa is shown in Figure 8 . The idea is to produce hydrogen cost-effectively from wind and solar power in Africa, liquefy it for greater transport efficiency, store it in $\mathrm{LH}_{2}$ tanks or LOHC, and ship it to Europe. Local deliveries can be made to the industrial sites in appropriate tanks by truck.

The solar and wind power plants as well as the electrolyzers are to be provided from Germany. The water required for electrolysis is to be obtained from the sea using renewable electricity by desalination. The plants for seawater desalination are also to be supplied from Germany.

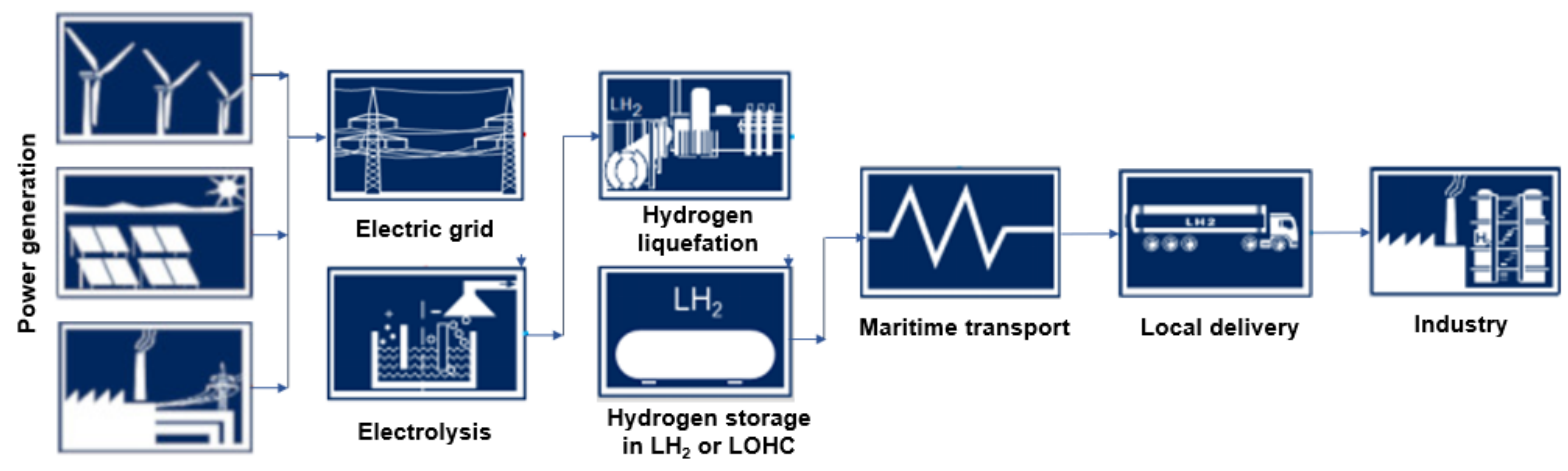

Figure 8. Delivery path - green hydrogen from Africa [9].

\section{Green and Blue Hydrogen from the OPEC Countries}

The OPEC states, especially the Gulf countries and North Africa are the other potential hydrogen suppliers. These countries have the unique opportunity to no longer (only) supply Europe and the world with crude oil and natural gas, ultimately hydrocarbon fuels, but with pure $\mathrm{CO}_{2}$-free hydrogen. This is possible from North Africa via the existing natural gas pipelines or from the Gulf countries using liquid hydrogen by tanker.

The Gulf countries are the ideal future manufacturer and supplier of green hydrogen because of the very inexpensive production of electricity from solar power plants. The enormous demand for green hydrogen for the sectors transportation, industry, households etc. cannot be produced easily from the sources available in Germany and Europe. In this way, the Gulf countries can already counter a possible drop in prices and the loss of importance of crude oil and natural gas due to the steadily increasing e-mobility and (over)compensate for this by supplying hydrogen [17]. 


\section{Conclusions}

Hydrogen can make a key contribution to decarbonization - it is a sustainable energy carrier whose combustion product is only water.

By 2050, as part of the German energy transition ("Energiewende"), there will be a considerable need for hydrogen for the provision of non-fossil fuels. However, the ecological relief effects of hydrogen (i) depend on the degree of conversion, but a significant decarbonization is only possible through the use of hydrogen (ii) if it is produced with low emissions. The currently ready-to-use gray hydrogen produces approximately $13 \mathrm{~kg} \mathrm{CO} / \mathrm{kg} \mathrm{H}_{2}$, while blue and turquoise hydrogen still produce approximately $6 \mathrm{~kg} \mathrm{CO}_{2} / \mathrm{kg} \mathrm{H}_{2}$ - due to the upstream chain emissions of natural gas and methane leaks [15]. Even the procurement of green hydrogen is not entirely without $\mathrm{CO}_{2}$ pollution. Its emission factor of $0.88 \mathrm{~kg} \mathrm{CO}_{2} / \mathrm{kg} \mathrm{H}_{2}$ is due to the energy used in the upstream chain to produce its supply technology, e.g. wind power and PV systems plus electrolyzers [15]. A complete examination of the ecological relief effects through the use of renewable hydrogen must be considered separately for each consumer, industry or process.

Currently, around $96 \%$ of the world's hydrogen is produced using fossil energy sources [18]. The future need for green hydrogen poses major challenges for the RES and electrolysis markets. According to forecasts, the green hydrogen volumes ultimately required from renewable sources cannot be made available on an industrial scale until 2040. As an interim solution, fossil-based hydrogen could be used, such as blue or turquoise hydrogen. The use of blue hydrogen must, however, be questioned critically because it requires an available CCS infrastructure, but CCS is socially not accepted. The turquoise hydrogen is an attractive solution, as the natural gas could be decarbonized directly in the vicinity of its production source. The only by-product is graphite, which can be stored or used industrially without $\mathrm{CO}_{2}$ emissions.

The future German demand for renewable hydrogen cannot be met only by German domestic production. In addition to its own production volumes, Germany needs a powerful but sustainable external energy policy, because even in the age of renewable energies there will be limited energy imports. The following import options should be considered:

(i) green hydrogen from West and South Africa,

(ii) blue and turquoise hydrogen from Russia and

(iii) green, maybe blue/ turquoise hydrogen from the Middle East/ North Africa (MENA).

These partnerships can help the partner countries set up the relevant structures and ensure that the imported energy can be generated sustainably and under socially just conditions. However, the partner countries' own supply of renewable energies must always have priority over exporting to Europe.

\section{References}

[1] Energiedaten - nationale und internationale Entwicklung. www.bmwi.de. Accessed 2020 October 23.

[2] Prognose der Bevölkerung in den Kontinenten in den Jahren 2020 und 2100. https://de.statista.com/statistik/daten/studie/184686/umfrage/weltbevoel kerung-nachkontinenten/. Accessed 2021.

[3] Verne J. The Misterious Island" [Reprint of: L'Île mystérieuse, 1874]. Ware (Hertfordshire): Wordsworth Editions Ltd; 2010.

[4] Töpler J, Lehmann J, eds. Hydrogen and Fuel Cell: Technologies and Market Perspectives. Berlin-Heidelberg: Springer; 2017. https://doi.org/10.1007/978-3-662-44972-1 
[5] Eine kleine Wasserstoff-Farbenlehre. https://www.bmbf.de/de/eine-kleine-wasserstofffarbenlehre-10879.html. Accessed 2021.

[6] The National Hydrogen Strategy. BMWi [German Federal Ministry for Economics and Technology]; 2020.

[7] Brdička R. Grundlagen der physikalischen Chemie. 15. ed. Berlin: VEB Dt. Verl. d. Wiss.; 1985.

[8] Wasserstoff - Schlüssel zu weltweit nachhaltiger Energiewirtschaft - Beispiele aus Nordrhein-Westfalen von der Herstellung bis zur Nutzung. EnergieAgentur.NRW; 2013.

[9] Gribova M. Transition of the Fossil Energy Supply into the Hydrogen Based Economy of the Future. UAS [TH] Wildau; 2020.

[10] Crack it: Fossile Energie ohne Klimagase. - IASS und KIT entwickeln Technologie zur Erzeugung von Wasserstoff aus Methan ohne Kohlendioxid-Emissionen.

https://www.kit.edu/kit/pi 2015139 crack-it-fossile-energie-ohne-klimagase.php. Accessed 2015.

[11] Schnurnberger W, Janßen H, Wittstadt U. Wasserspaltung mit Strom und Wärme. In: Stadermann G, ed. Wasserstoff und Brennstoffzellen - Energieforschung im Verbund. Themenheft 2004. Berlin: Forschungsverbund Sonnenenergie; 2005:51.

[12] Brinner S, Schmidt M, Wagener L, Zuberbühler U. Technologiebericht 4.1 Power-to-gas (Wasserstoff) - Technologien für die Energiewende - Teilbericht 2 [to BMWI]. Wuppertal/ Karlsruhe/ Saarbrücken: Wuppertal Institut; 2018.

[13] Zukunft Erdgas e.V.. Power-to-Gas Verfahren. https://www.energieexperten.org/erneuerbare-energien/oekostrom/sektorkopplung/power-to-gas. Accessed 2021.

[14] Bukold S. Kurzstudie Blauer Wasserstoff - Perspektiven und Grenzen eines neuen Technologiepfades. Hamburg: Greenpeace Energy; 2020.

[15] Potenzialatlas Wasserstoff: woher soll der Grüne Wasserstoff kommen?. https://www.bmbf.de/de/woher-soll-der-gruene-wasserstoff-kommen-11766.html. Accessed 2021.

[16] Sturm H. Grüner und blauer Wasserstoff aus den OPEC-Staaten. https://www.pvmagazine.de/2019/10/08/gruener-und-blauer-wasserstoff-aus-den-opec-staaten/. Accessed 2019.

[17] Weger L, Abánades A, Butler T. Methane cracking as a bridge technology to the hydrogen economy. International Journal of Hydrogen Energy. 2017 01;42(1):720-731. https://doi.org/10.1016/j.ijhydene.2016.11.029 